Zusammenfassung. Die Fundoplicatio ist die sicherste und am besten untersuchte Antirefluxoperation. Voraussetzung für ein gutes Ergebnis ist eine sorgfältige Indikationsstellung zur Operation und eine einwandfreie Operationstechnik. Beides wird im Film detailliert dargestellt. Bei fehlerhafter Operationstechnik ist mit der Entwicklung von sogenannten Post-Fundoplicatio-Syndromen zu rechnen, die ebenfalls aufgezeigt werden.

Schliusselwörter: Fundoplicatio - Refluxkrankheit - Post-Fundoplicatio-Syndrom.

\title{
326. Endobrachyoesophagus und Adenocarciom
}

\author{
J. R. Siewert und H. Hildebrand
}

Chirurgische Klinik und Poliklinik der Technischen Universiät München, Klinikum rechts der Isar, Ismaninger Straße 22, D-8000 München 80

\section{Columnar Cell-Lined Lower Esophagus and Adenocarcinoma}

Summary. The columnar cell-lined lower esophagus represents potential precancerosis. If an adeno carcinoma develops in the distal esophagus, it has to be treated as a carcinoma of the esophagus. The film shows the surgical technique of subtotal esophagectomy with simultaneous replacement of the esophagus by means of the stomach. Here a special intrathoracic anastomosis is demonstrated, which provides a high safety rate.

Key words: Columnar cell-lined lower esophagus - Subtotal esophagectomy - Esophageal replacement.

Zusammenfassung. Der Endobrachyoesophagus (Auskleidung des distalen Oesophagus mit Zylinderepithel statt mit Plattenepithel) stellt eine fakultative Präcancerose dar. Entsteht im distalen Oesophagus ein Adenocarcinom, so muß es wie ein Oesophaguscarcinom behandelt werden. Der Film zeigt die chirurgische Technik der subtotalen Oesophagektomie mit einzeitigem Ersatz der Speiseröhre durch Magen. Dabei wird eine spezielle intrathorakale Anastomose vorgestellt, die ein Höchstmaß an Sicherheit bietet.

Schliisselwörter: Endobrachyoesophagus - Subtotale Oesophagektomie - Speiseröhrenersatz.

\section{Der Pfortaderhochdruck und seine Komplikationen}

\author{
E. Ungeheuer, J. Cappel. U. Blum und E. März \\ Chirurgische Klinik des Krankenhauses Nordwest, Steinbacher Hohl 2-26, D-6000 Frankfurt/Main
}

\section{Portal Hypertension}

Summary. The main cause of portal hypertension is cirrhosis of the liver, most often alcoholic cirrhosis. The main complications of portal hypertension are hemorrhage due to esophageal piles, ascites, encephalopathy and splenomegaly. The modern operative treatment of portal hypertension and the indication of operative and nonoperative treatment are explained. New operation techniques are demonstrated, and their results in patients operated on in our hospital are discussed.

Key words: Portal hypertension - Hemorrhage - Ascites - Operative treatment.

Zusammenfassung. Häufigste Ursache der portalen Hypertension ist die Lebercirrhose, hierbei führend die alkoholtoxisch bedingte Cirrhose. Die wichtigsten Komplikationen der portalen Hypertension sind die akute Blutung aus Oesophagusvaricen, der Ascites, die Encephalopathie und die Splenomegalie. Es werden die derzeitigen Möglichkeiten der operativen Therapie aufgezeigt und der Indikationsbereich der operativen und konservativen Therapie abgegrenzt. Neue chirurgische Behandlungstechniken werden vorgestellt und ihre Ergebnisse anhand unseres großen Krankengutes demonstriert.

Schliusselwörter: Pfortaderhochdruck - Oesophagusvaricenblutung - Ascites - Operative Behandlung. 